専門医症例報告

\author{
咀嚼および審美障害に対して補綴処置を行った 1 症例 \\ 小田切 憲
}

\title{
A Case of Prosthetic Rehabilitation for Disability of Chewing and Aesthetics Problem
}

\section{Ken Odagiri}

抄 録

症例の概要：患者は 60 歳，女性。咀嚼および審美障害を主訴に来院した。重度の慢性歯周炎患者に対し 即時義歯を装着し，早期に咬合の支持，審美性を回復させ経過を観察しながら最終補綴処置に移行した. 考察：即時義歯を装着したことにより，歯の欠損による咀嚼障害や審美障害などの弊害が最小限となり， 最終補綴処置に至るまでに十分な前処置が行えた。

結論：本症例では, 即時義歯を使用して適正な下顎位および咬合高径を与えることによって機能的, 審美 的ともに患者の満足を得ることができた。 また，重度の慢性歯周炎患者の補綴装置として，可撤式部分床 義歯は有効な処置法であると考えられる.

和文キーワード

即時義歯, 審美障害, 咀嚼障害

\section{ABSTRACT}

Patient: This case report describes the use of immediate denture in a severe case of chronic periodontitis. A 60-year-old female patient presented with a chief complaint of disability of chewing and aesthetics problem. An immediate denture was served to achieve adequate occlusion. Due to applying of immediate denture in early stage, her occlusion and aesthetic problem were improved, and final prosthetics treatment performed.

Discussion: According to immediate denture, her chewing disability and aesthetic problem were improved, and time was allowed to perform pre-treatment before final prosthetic treatment.

Conclusion: The aim of this case report is to show achievement of a functionally and aesthetically satisfying result with applying immediate denture. In addition, it is thought that removable partial denture is an effective treatment as a prosthetic device of a severe case of chronic periodontitis.

\section{Key words}

immediate denture, aesthetic problem, chewing disability 


\section{I. 緒 言}

下顎の偏位や咬合関係の不調和は，重度の慢性歯周炎 による歯の動摇あるいは歯の欠損により惹起されること が多くその結果, 咀嚼および審美障害をもたらす。今回, 重度の慢性歯周炎患者に対し即時義歯を装着し，早期に 咬合の支持，審美性を回復させ経過を観察しながら最終 補綴処置へ移行し良好な結果が得られたので報告する.

\section{II. 症例の概要}

\section{1. 症例}

患者: 60 歳，女性.

初診: 平成 14 年 5 月 13 日.

主訴：上顎左側大臼歯部が痛む。

全身的既往歴：特記事項なし.

現病歴: 平成 14 年 4 月頃から上顎左側大臼歯部が咀 嚼時にうずくような痛みがあり来院した。

\section{2. 診査・検査所見}

上顎は $6522 \mid 257$ 欠損で，欠損部に対し (4)5 6)ブ リッジ，65部分床義歯が装着されていた。 $3 \mid 3$ は近

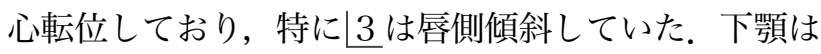
$765 \mid 57$ 欠損, $4 \mid 6$ にクラウンが装着されていた（図 1). X 線写真および歯周組織検査の結果, 上顎臼歯部 と下顎前歯部に重度の歯槽骨吸収とその他の部位に中等 度の歯槽骨吸収が認められた（図 2，3）。咬合関係は左 側臼歯部に交叉咬合，下顎左側偏位，過蓋咬合，咬合平 面の不正が認められた。

\section{3. 治療方針}

はじめに歯周初期治療を行い, 保存不可能な歯は抜歯 し，即時義歯を装着し咬合支持を回復させる，迈の唇 側傾斜について支台歯としては不適切であったため矯正 治療および歯周外科処置を勧めたが患者の同意が得られ なかったため便宜抜髄を行い, 歯軸を改善する. 残存歯 については陶材焼付鋳造冠で一次固定し支台歯の負担能 力の補強を行い, 歯の動摇と歯冠歯根比を改善する. そ の後, 審美性と機能性を考慮して I バークラスプを応用 した金属床義歯を製作することとした。

\section{III. 治療内容と経過}

\section{1. 治療内容}

まず，歯周基本治療後，保存不可能と判断した 74
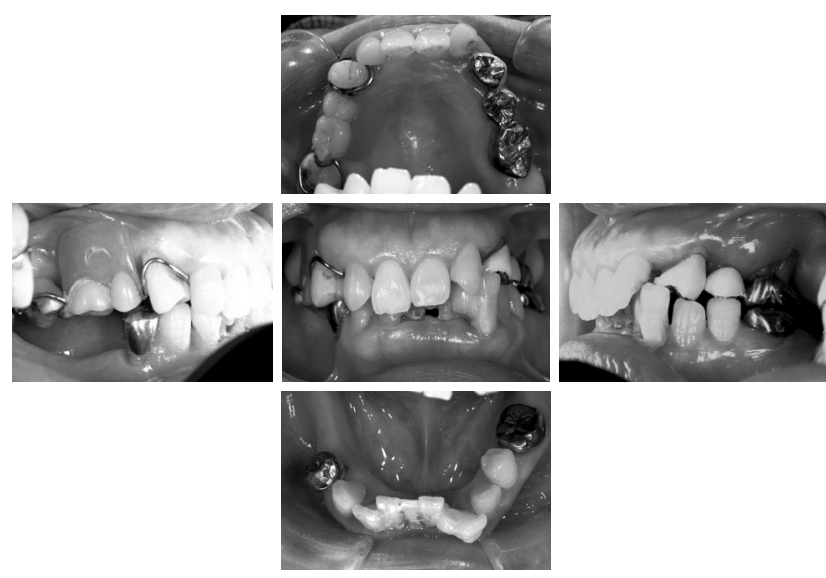

図 1 Intraoral views at the first visit 初診時の口腔内写真

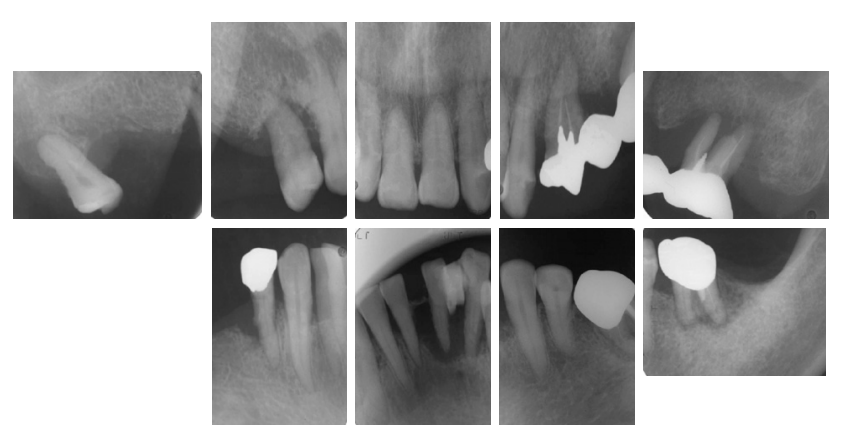

図 2 Dental radiographs at the first visit 初診時のデンタル X 線写真

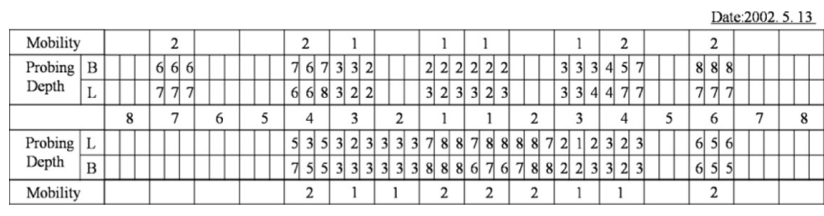

図 3 Examination of periodontal status at the first visit 初診時の歯周組織検査

$46 \overline{41 \mid 126}$ を抜歯し，同日に即時義歯を装着し 咬合支持を回復させた。即時義歯は $3|3 \quad \overline{3}| 4$ にワイ ヤークラスプを用いたレジン床義歯とし，人工歯は調整 しやすいようにレジン歯を用いた．即時義歯装着後，3 カ月間の経過観察を行った（図 4，5）。3 は唇側傾斜 しており支台歯としては不適切であったため便宜抜髄 し，18k 金合金で支台築造して歯軸を改善した。最終 補経は $3 \quad 1|l| 3$ 陶材焼付鋳造冠を連結固定し, 舌側に ガイドプレーンと結節レストを設計した。また，迈の 歯䅡部に歯肉退縮が認められたため歯肉色のピンクポー セレンを用いて審美性を改善した。下顎も同様に 32 34 陶材焼付鋳造冠でそれぞれ連結固定し舌側にガ 

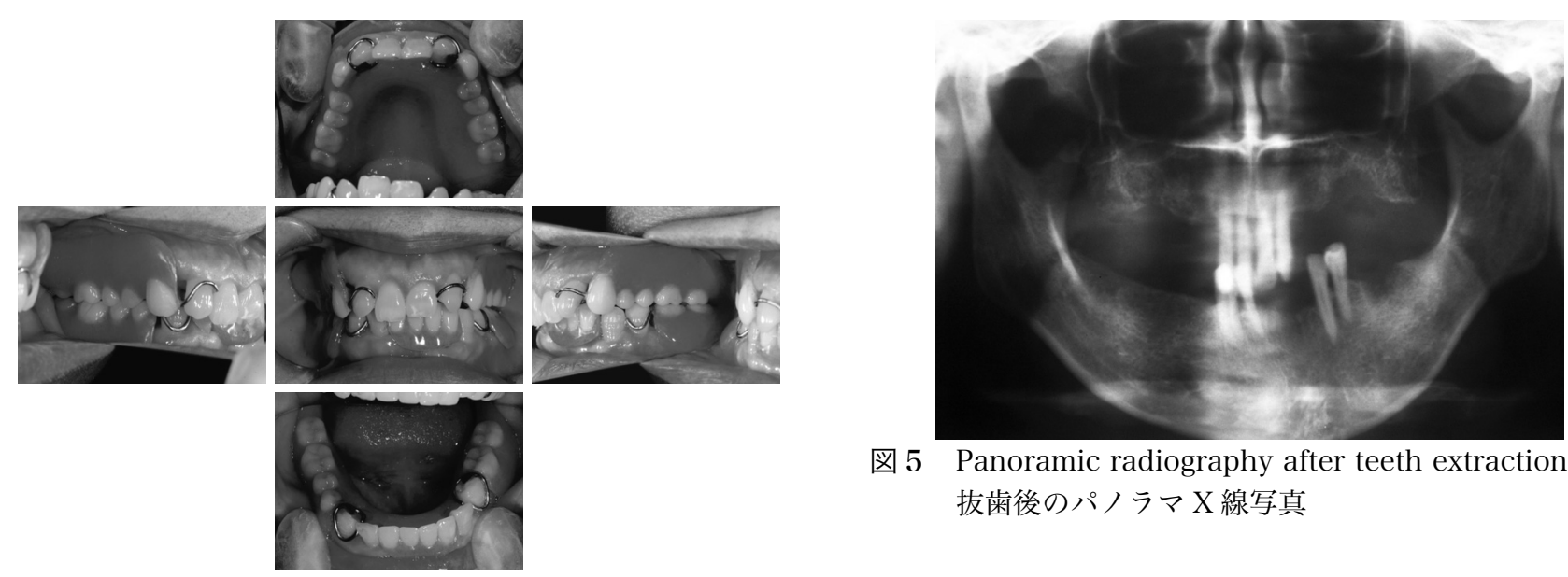

図 5 Panoramic radiography after teeth extraction 抜歯後のパノラマ X 線写真

図 4 Intraoral views after teeth extraction 抜歯後の口腔内写真
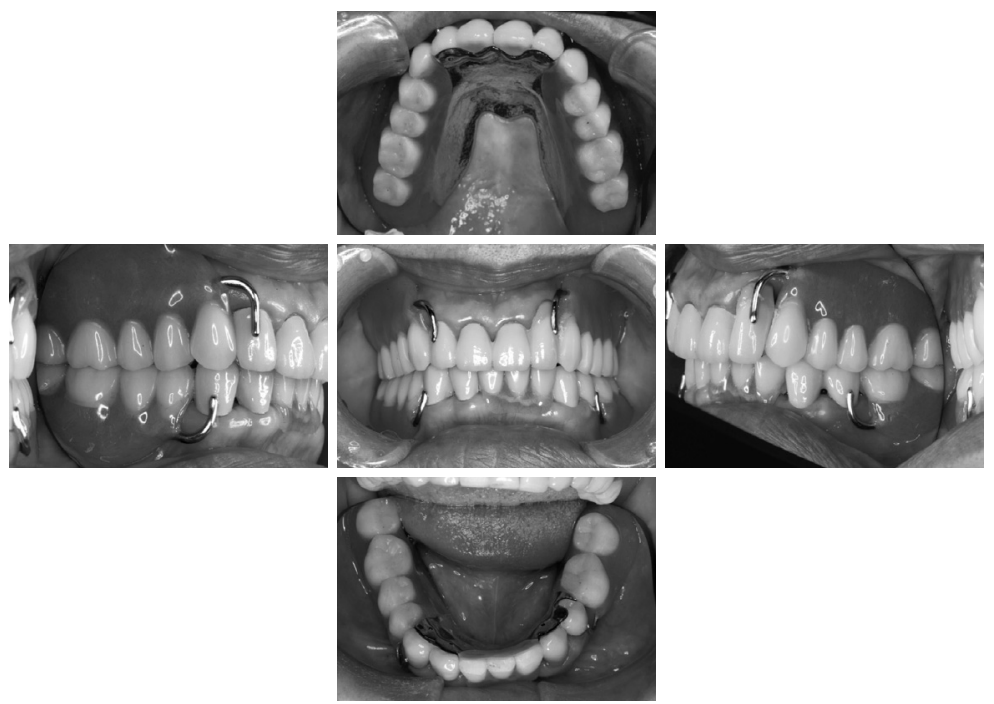

図 6 Intraoral views after insertion of the final restoration 最終補経装置装着時の口腔内写真

〔満足度の評価〕－筫問票一

(J Prosthet Dent 1999; 82: 416-427)

旧義歯上比較した新義歯の満足度に関する質問 11 項目に対して，7段階評価て回答を求めたところ, 全項目において満足度が最も 高い“(7)以前よりも烃めて息い”回管が得られた。

(1)以前の義歯と比べて現在の義歯てどのくらい良く食事ができますか？

(2)以前の義歯と比べて現在の義歯で快適性を感じます加?

(3)現在の義歯で固い食べ物を食べたとき，以前の義歯と比べてどのくらいよく食事が出来ますか？

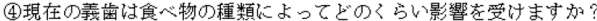

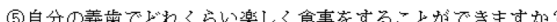

(6)以前の義歯と比へて現在の義歯をきれいに清掃することがどのくらい難しいですか?

(7)以前の義歯上比心゙て現在の義歯の清潔度によ゙のくらい満足していますか?

(8)以前の舟歯上比べて現在の義歯でら゙のくらいたおい感じますか?

(9)以前の義歯上比へて現在の義歯ていらもにおいを感します加?

(10以前の義歯と比べて自分の義歯に対してどれくらい安心感安持っていますか？

(11)以前の義歯上比心て現在の義歯はどのくらい発音に影響を及ぼしますか？

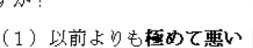

(2) 以前よりもがり悪い

（3）以前よりも僅加に悪い

(4) 以前上同し

(5)以前よりも僅かに良い

(6) 以前よりも加机り息い

（7）以前よりも桎あて息い

図 7 Questions and example of response choices for patient assessment of new dentures

新義歯の患者評価に関する質問および回答表 


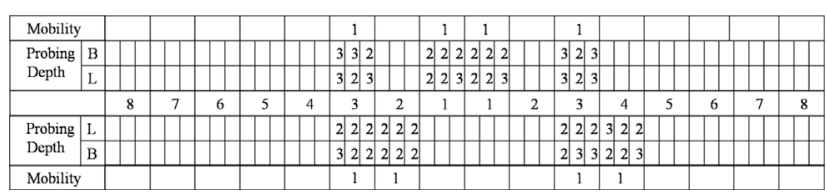

図 8 Examination of periodontal status at 4 years after prosthetic treatment 補経治療終了 4 年後の歯周組織検査

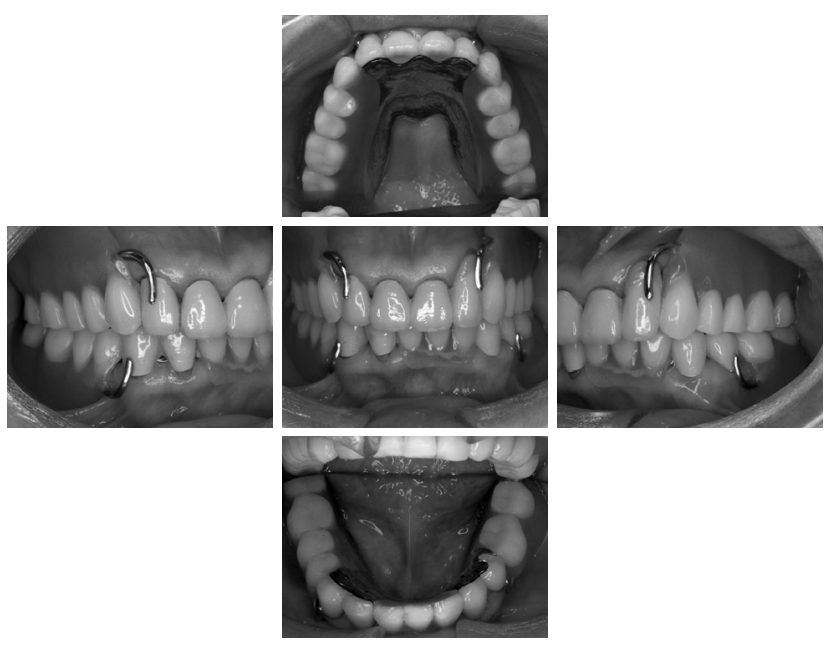

図 9 Intraoral views at 4 years after prosthetic treatment 補経治療終了 4 年後の口腔内写真

イドプレーンと咬合面レストを設計して製作した。 76

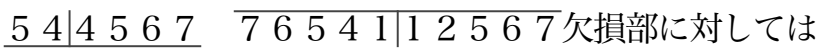
I バークラスプを応用した金属床義歯を製作した（図 6).

\section{2. 経過}

最終補綴装着後, 満足度の主観的評価として旧義歯と 比較した新義歯の満足度に関する質問 11 項目に対して 7 段階評価で回答を求めたところ, 全項目において満足 度が最も高い “(7) 以前よりも極めて良い” 回答が得 られた (図 7) ${ }^{1)}$.

定期的に経過観察し，口腔清掃指導の徹底を行いプラ ークコントロールは良好である（図 8)。装着後 4 年以 上経過しているが，機能・審美性ともに十分な満足度が 得られている(図 9)。

\section{IV. 考 察}

本症例は即時義歯を装着した結果，歯の欠損による咀 嚼障害や審美障害などの弊害が最小限となり, 最終義歯 に至るまでに十分な前処置が行えたことが，患者の満足 度が高かつた要因の一つであると推測する。

残存歯を陶材焼付鋳造冠で一次固定して支台歯の補強 を行ったことで歯の動摇と歯冠歯根比は改善した.さら に，クラウンはガイドプレーンと強固なレストを設計し たことで義歯の回転を防止し，同時にすべての残存歯に 力が分散するようにしたことも成功した一因である ${ }^{2)}$. 反省点としては， 13 の唇側傾斜に対して矯正治療およ び歯周外科処置を行っていれば，より審美的で清掃性の 良い補綴装置を装着できたと考えられる。

\section{V. 結 論}

本症例では，即時義歯を使用して適正な下顎位および 咬合高径を与えることによって機能的，審美的ともに患 者の満足を得ることができた。 また，重度の慢性歯周炎 患者の補経装置として, 可撤式部分床義歯は有効な処置 法であると考えられる。

\section{文献}

1) Kapur KK, Garrett NR, Hamada MO, Roumanas ED, Freymiller E, Han T et al. Randomized clinical trial comparing the efficacy of mandibular implant-supported overdentures and conventional dentures in diabetic patients. Part III: Comparisons of patient satisfaction. J Prosthet Dent 1999; 82: 416-427.

2）野首孝祠，五十嵐順正．現代のパーシャルデンチャー欠 損補綴の臨床指針。東京：クインテッセンス出版； 2000, 51-149.

著者連絡先 : 小田切 憲

T 238-8580 神奈川県横須賀市稲岡町 82

TEL: 046-822-8884

FAX: 046-822-8861

E-mail: shake@kdcnet.ac.jp 